\title{
The Peptides of the Hyphal Wall of Neurospora crassa
}

\author{
By C. R. WRATHALL AND E. L. TATUM \\ The Rockefeller University, I230 York Avenue, New York, New York $1002 \mathrm{I}$
}

(Received 6 March 1973)

\begin{abstract}
SUMMARY
The peptides of the hyphal wall of Neurospora crassa have been studied to determine their physical characteristics. We have removed these peptides from the wall by treatment with $0.5 \mathrm{M}-\mathrm{NaOH}$ and shown by DEAE cellulose chromatography that there are five major fractions present. Amino acid analysis showed distinct differences in primary structure between these fractions but similarities in the proportions of hydrophilic residues and the ratios of basic residues to acidic residues of each fraction. Two unknown compounds, one acidic and the other basic, were also detected.

Extraction of the wall with $\mathrm{NH}_{4} \mathrm{OH}$ released a high molecular weight glycopeptide complex, from which the peptides were released with $\mathrm{NaOH}$. $O$-Glycosyl serine linkages were demonstrated to occur within this complex.

Enzyme digestion of either the chitin or the $\beta$-I,3-polymer of the hyphal wall failed to release peptide material. This, together with the above, suggests that the glycopeptide of the hyphal wall is a highly ordered structure of peptides joined by a branched carbohydrate linker of unknown composition, and that it is not demonstrably covalently linked to the other major components of the wall. It probably occurs in vivo as an extremely large structure embedded in the other polymers of the hyphal wall.
\end{abstract}

\section{INTRODUCTION}

The hyphal wall of the fungi has received considerable study as it is this portion of the organism which determines morphology and growth patterns. The chemical composition of the walls of many fungi has been studied (for review, see Bartnicki-Garcia, I968) in an attempt to determine if alterations in this structure may lead to specific alterations in morphology. Considerable attention has been paid to the structure of the carbohydrate elements of the wall, but little has been given to other components. This is not unexpected, as polysaccharides make up 80 to $90 \%$ of the hyphal wall, the remainder being lipid and protein. This has resulted in a paucity of information concerning the role these minor constituents play in determining morphology.

Since the first report of proteinaceous material in the wall of yeast (Eddy, I958), there have been several reports of the presence of amino acids as a product of hydrolysis of the cell walls of various fungi. Suomalainen and his co-workers (Nurminen, Oura \& Suomalainen, 1970) have described enzymatic proteins which are associated with the wall of yeast, and Northcote and co-workers have shown the presence of glycopeptide components on the wall of baker's yeast (Korn \& Northcote, I960; Sentandreu \& Northcote, I968).

The presence of a protein component of the hyphal wall of Neurospora crassa was established by de Terra \& Tatum (1963) and Mahadevan \& Tatum (1965). The latter showed the presence of amino acids in acid hydrolysates of the whole hyphal wall and of their Fraction I, which is the first base-soluble fraction of the wall. Manocha \& Colvin (1967) have reported the presence of proteinaceous material in the wall of this organism which could be 
liberated by digestion of the polysaccharide portions of the wall with hydrolytic enzymes. They concluded, on the basis of electron microscopy, that this protein material forms a discrete layer within the wall, and that it also lines pores within the wall. Hunsley \& Burnett (1970) have also studied the wall of $N$. crassa by enzymatic digestion of various components, followed by examination by electron microscopy. They support the contention that the protein exists as one of a series of concentric layers which make up the cell wall. Enzymatic proteins have also been found to be associated with the hyphal wall of $N$. crassa (Eberhart, I96I ; Mahadevan \& Mahadkar, I970; Trevithick \& Metzenberg, I966a), and their location (Chang \& Trevithick, I972 b), relationship to the wall (Chang \& Trevithick, I972a) and function (Mahadevan \& Mahadkar, 1970) have been described.

Two classes of wall-associated proteins thus exist. First, those of enzymatic function which are not associated with the wall structure per se, but are 'in transit' to the external medium (Trevithick \& Metzenberg, 1966a) or trapped within the structure of the growing wall (Chang \& Trevithick, 1972a). The second class is that described above as participating in determining the morphology of the wall itself (Hunsley \& Burnett, 1970; Manocha \& Colvin, 1967). No work has been reported concerning the physical characteristics, such as subunit structure and molecular weight, of this conponent of the fungal cell wall. This report describes the initial experiments towards establishing the structure of this interesting component of the hyphal wall of Neurospora crassa.

\section{METHODS}

Growth of organisms and preparation of hyphal wall. Neurospora crassa, wild-type strain RL 3-8A from the Rockefeller University, was grown in I5 1 carboys with Vogel's (1964) Medium $\mathrm{N}$ using $2 \%$ sucrose as the carbon source. The carboys were inoculated with mycelia sheared in a Waring Blender. Mycelium was harvested on filter paper, washed thoroughly with distilled water and lyophilized. The dried material was ground in a mortar and stored at $4{ }^{\circ} \mathrm{C}$. Hyphal walls were prepared by a modification of the method of Mahadevan \& Tatum (1965). The ground mycelium was suspended in $2 \%$ sodium lauroyl sarcosinate (I g mycelia/I00 ml) and stirred in the cold overnight. After thorough washing with distilled water by centrifugation, the suspension of hyphal walls was dialysed overnight at $4{ }^{\circ} \mathrm{C}$ against distilled water and lyophilized. The walls were found to be free of cytoplasmic contamination by phase-contrast microscopy.

Strain H605-I-3A (serine-I, F.G.S.C. no. I I6), a serine auxotroph, was grown on liquid Vogel's Medium N supplemented with $0.1 \mathrm{mg}$ serine and $0.5 \mathrm{mg}$ alanine $/ \mathrm{ml}$, together with $6.25 \mu \mathrm{C}$ of uniformly labelled $\left[{ }^{14} \mathrm{C}\right]$ serine (Schwartz-Mann, Orangeburg, New York, U.S.A.). Harvesting and preparation of hyphal wall were as above.

Preparation of hyphal wall peptides. Hyphal wall was suspended $(10 \mathrm{mg} / \mathrm{ml})$ in $0.5 \mathrm{M}-$ $\mathrm{NaOH}$ and stirred at $4{ }^{\circ} \mathrm{C}$ overnight. The suspension was filtered through glass-fibre filter paper under vacuum and two volumes of absolute ethanol added to the filtrate. After $2 \mathrm{~h}$ at $4{ }^{\circ} \mathrm{C}$, the resulting precipitate, which contained a polygalactosamine polymer (Fraction I of Mahadevan \& Tatum, I965), was removed by filtration and the filtrate brought to $\mathrm{pH} 7.6$ with $\mathrm{HCl}$. The ethanol was removed by rotary evaporation under vacuum. The peptides were desalted by passing them through a column of Bio-Gel P-2 (Bio-Rad Laboratories, Richmond, California, U.S.A.), with $0.2 \mathrm{M}-\mathrm{NH}_{4} \mathrm{OH}$ as the eluant. The peptidecontaining fractions, identified by absorbance at $280 \mathrm{~nm}$, were combined and the $\mathrm{NH}_{4} \mathrm{OH}$ removed by rotary evaporation under vacuum.

Peptide material was also released from the wall by treatment with $25 \% \mathrm{NH}_{4} \mathrm{OH}$ for $3 \mathrm{~h}$ at $37{ }^{\circ} \mathrm{C}$ with stirring. The suspension was filtered, the $\mathrm{NH}_{4} \mathrm{OH}$ removed from the filtrate 
by rotary vacuum evaporation and the resulting solution chromatographed on a column of Bio-Gel P-I 50, 50 to I00 mesh. Material removed from the wall with $\mathrm{NH}_{4} \mathrm{OH}$ was also subjected to gel-filtration chromatography on a column of Bio-Gel A 0.5 M in o. IM- $\mathrm{NH}_{4} \mathrm{HCO}_{3}$ ( $\mathrm{pH} 9.0$ ) with $6 \mathrm{M}$-urea. The sample was incubated in the same buffer at $37^{\circ} \mathrm{C}$ for $3 \mathrm{~h}$ before application to the column. The protein-containing fractions were identified by absorbance at 257 and $280 \mathrm{~nm}$.

Acid extraction of the hyphal wall was performed by suspending the wall (Io $\mathrm{mg} / \mathrm{ml}$ ) in I $\mathrm{N}-\mathrm{HCl}$ and stirring the suspension for $10 \mathrm{~min}$ at room temperature. The residue was separated from the extract by filtration as before and the acid removed by lyophilization. The remaining material was dissolved in distilled water made slightly basic by the addition of $\mathrm{NH}_{4} \mathrm{OH}$.

Quantitation. Estimation of protein concentration was attempted using both the Biuret method (Gornall, Bardawill \& David, I949) and that of Lowry, Rosebrough, Farr \& Randall ( $195 \mathrm{I}$ ). The response curve given by hyphal wall peptide with both these tests was not linear over a concentraion range in which bovine serum albumin gave a linear response, and so these methods of estimation were not used. Basic hydrolysis (see below) was found to produce a linear response and so was used to measure the protein present. The sample was dissolved in $\mathrm{I} \mathrm{ml}$ of $\mathrm{I} \cdot \mathrm{O} \mathrm{M}-\mathrm{NaOH}$, placed in a polyethylene centrifuge tube and $0.1 \mathrm{ml}$ of Io $\mathrm{M}-\mathrm{NaOH}$ added. The solution was heated for $3 \mathrm{~h}$ at $\mathrm{I} 30^{\circ} \mathrm{C}$, cooled and brought to $\mathrm{pH} 5.5$ with acetic acid. The amino acids present were measured with sodium propionate-ninhydrin reagent (Rosen, Berard \& Levenson, 1962) against a standard of leucine. Molecular weights of 3800 for the peptides and 100 as the average amino acid were assumed in order to translate the quantity of amino acids present to $\mathrm{mg}$ of protein.

Column chromatography. The peptides were separated on a $2 \times 20 \mathrm{~cm}$ column of DEAE cellulose (Schleicher \& Schuell, Keene, New Hampshire, U.S.A.) equilibrated with 0.00 I Mtris- $\mathrm{HCl}, \mathrm{pH} 7 \cdot 4$. The sample was applied and washed on the column with the same buffer. The chromatogram was developed with a $600 \mathrm{ml}$ linear gradient, with $0.00 \mathrm{I} \mathrm{M}$-tris- $\mathrm{HCl}$, $\mathrm{pH}_{7} .4$, as the starting buffer and $0.5 \mathrm{M}-\mathrm{NaCl}$ in $0.00 \mathrm{I} \mathrm{M}$-tris- $\mathrm{HCl}, \mathrm{pH} \mathrm{7.4}$, as the final buffer. The effluent was monitored at $280 \mathrm{~nm}$ and $\mathrm{I} 0 \mathrm{ml}$ fractions were collected.

DEAE cellulose chromatography was also performed in the presence of urea, to ascertain if the peptides eluted from the standard DEAE cellulose columns were stable aggregates. The conditions (column size, buffer and elution gradient) were the same as above, except that 6 M-urea (Ultra-pure, Schwarz-Mann, Orangeburg, New York, U.S.A.) was incorporated into the buffers. The peptide sample, either whole wall extract or DEAE cellulose fractions, was dissolved in tris-urea and incubated for $3 \mathrm{~h}$ at $37^{\circ} \mathrm{C}$ in a water bath. This material was then applied to the column and the chromatogram developed.

Gel filtration to determine molecular weights was performed on a column of Bio-Gel P-6o, Ioo to $200 \mathrm{mesh}$. The column dimensions were $\mathrm{I} \cdot 5 \times 80 \mathrm{~cm}$. The eluant was $\mathrm{O} \cdot \mathrm{I} \mathrm{M}$-tris- $\mathrm{HCl}$, $\mathrm{pH} \mathrm{7.4}$, containing $8 \mathrm{M}$-urea and $0.5 \mathrm{M}-\mathrm{NaCl}$. One-ml fractions were collected and analysed by absorbance at $210 \mathrm{~nm}$. Calibration standards were obtained by cyanogen bromide cleavage of horse-heart cytochrome $c$ and sperm-whale myoglobin (Sigma Chemical Co., St Louis, Missouri, U.S.A.) according to the method of Gross (1967).

Amino-acid analysis. The peptide mixture or fractions were freed of salt as described above and hydrolysed for $22 \mathrm{~h}$ with $6 \mathrm{~N}-\mathrm{HCl}$ at $105{ }^{\circ} \mathrm{C}$ in evacuated tubes. The $\mathrm{HCl}$ was removed by rotary evaporation. Amino acids were separated and measured with a Durrum Amino Acid Analyser (Durrum Chemical Corp., Palo Alto, California, U.S.A.) after the method of Spackmann, Stein \& Moore (1958). Durrum pico buffers were used for analysis. 
Identification of linkage amino acid. Strain $\mathrm{H} 605$ was grown and hyphal walls prepared as described. A portion of the wall was suspended in a solution containing $0.25 \mathrm{M}-\mathrm{NaOH}$ and $0.3 \mathrm{M}^{-\mathrm{NaBH}_{4}}$ (Ventron, Beverly, Massachusetts, U.S.A.) and stirred overnight at $4{ }^{\circ} \mathrm{C}$. The suspension was filtered, ethanol added and the suspension filtered again. Excess $\mathrm{NaBH}_{4}$ was removed by acidification and addition of methyl alcohol, followed by flash evaporation. The remaining material was passed through a Bio-Gel P-2 column and the peptide-containing fractions were pooled and reduced in volume by flash evaporation. A portion of this radioactive peptide was hydrolysed with $6 \mathrm{~N}-\mathrm{HCl}$. The hydrolysate was chromatographed on cellulose thin-layer chromatography plates ('Mannogram', Schwarz-Mann, Orangeburg, New York, U.S.A.). The solvents used were: I, $n$-butanol : acetic acid:water ( $2: 3: 5$, by vol.); 2, phenol:ammonia (100: $1, \mathrm{v} / \mathrm{v}$ ); and 3, $t$-butanol:water:methyl ethyl ketone:diethylamine (80:80:40:8). Appropriate standards were run on outside channels of the same plate to identify the amino acids. Location was by spraying these outer channels with $\mathrm{I} \%$ ninhydrin in $n$-butanol. The unstained areas were collected in disposable pipettes by vacuum and the amino acids eluted from the cellulose with $0.01 \mathrm{M}$-acetic acid. Solvent systems I or 2 were used to separate alanine from serine and glycine. The serine-glycine mixture, which was not separated by solvent I, was concentrated and rerun in solvent 3 , which separates these two amino acids. The amino acids were eluted from the collected cellulose into $20 \mathrm{ml}$ scintillation vials and $15 \mathrm{ml}$ of Aquasol (New England Nuclear, Boston, Massachusetts, U.S.A.) added to each vial. Determination of radioactivity was accomplished in a liquid scintillation counter.

Radioactive hyphal wall peptide, isolated from walls by treatment with $0.5 \mathrm{~N}-\mathrm{NaOH}$ or I.O N-HCl, was also treated as described to determine the radioactivity in serine and alanine.

Hyphal wall digestion by enzymes. A $100 \mathrm{mg}$ portion of hyphal wall was suspended in $30 \mathrm{ml}$ sodium acetate buffer, $0.005 \mathrm{M}, \mathrm{pH} 6 \cdot 0$, together with $10 \mathrm{mg}$ chitinase (EC. 3.2 . I I4, Schwarz-Mann, Orangeburg, New York, U.S.A.) and incubated at $37^{\circ} \mathrm{C}$ in a shaking water bath. After $48 \mathrm{~h}$ an additional $\mathrm{I} 0 \mathrm{mg}$ of the enzyme was added and the digestion continued for $24 \mathrm{~h}$. The hyphal wall was then collected and washed three times with distilled water by centrifugation. A portion of the digested wall was analysed for the presence of glucosamine by acid hydrolysis followed by thin-layer chromatography. The remainder of the wall was treated with $0.5 \mathrm{~N}-\mathrm{NaOH}$ and the filtrate analysed for released protein material by basic hydrolysis.

The above procedure was repeated with Glusulase (Endo Laboratories, Garden City, New York, U.S.A.) which digests the $\beta$-I,3-carbohydrate polymer. The buffer was 0.0I M$\mathrm{K}_{2} \mathrm{HPO}_{4}$ plus $0.003 \mathrm{M}$-citric acid, $\mathrm{pH} 6.0$, and I ml of enzyme solution was added at each time period. Controls were hyphal walls suspended in buffer without enzymes and treated exactly as described for the enzyme digested walls.

\section{RESULTS}

Release of peptides from the hyphal wall. Portions of wall were suspended in $0.5 \mathrm{M}-\mathrm{NaOH}$ and incubated at $25{ }^{\circ} \mathrm{C}$ for varying periods of time to ascertain the time course of release of the peptides. Samples were filtered and the filtrate subjected to basic hydrolysis and ninhydrin quantitation. The kinetics of release are shown in Fig. I. Approximately $50 \%$ of the peptides were released during the first 30 min of treatment, with complete release being observed after $6 \mathrm{~h}$. This showed the extreme lability to strong base of the linkages which hold the peptides within the hyphal wall. Gel filtration of the material released by $\mathrm{NaOH}$ showed that this material was exclusively of low molecular weight. 


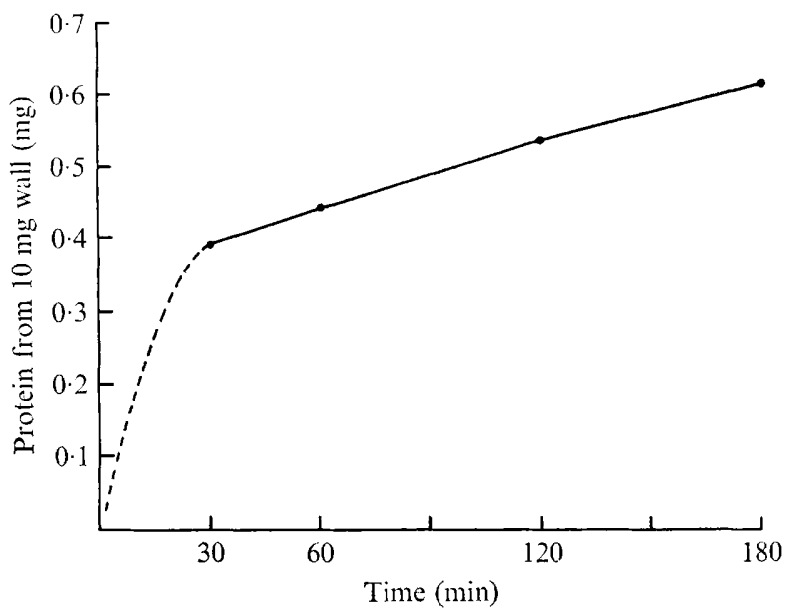

Fig. I. Release of peptide material from hyphal wall with $0.5 \mathrm{~N}-\mathrm{NaOH}$ at $25^{\circ} \mathrm{C}$. Each point is the average of duplicate determinations from each of three experiments.

Table I. Peptide material released from the hyphal wall by different extraction methods and comparison of acid and basic hydrolysis methods for measurement

Data given as percentage by weight of the hyphal wall.

\begin{tabular}{|c|c|c|c|}
\hline \multicolumn{2}{|c|}{$\mathrm{NaOH}$ treatment } & \multicolumn{2}{|c|}{ Hydrolysis } \\
\hline $\begin{array}{l}\text { Time } \\
\text { (h) }\end{array}$ & $\begin{array}{c}\text { Temperature } \\
{ }^{\circ} \mathrm{C}\end{array}$ & Acid* & Alkali $\dagger$ \\
\hline 6 & 25 & $\begin{array}{l}8 \cdot 23 \\
8 \cdot 42\end{array}$ & $\begin{array}{l}7 \cdot 59 \\
7 \cdot 50\end{array}$ \\
\hline I 8 & 4 & $8 \cdot 42$ & $7 \cdot 50$ \\
\hline
\end{tabular}

* Summation of individual amino acids after automatic amino acid analysis.

$\dagger$ Estimation by manual ninhydrin method.

To determine the most favourable method for the release of the peptides from the hyphal wall, portions were suspended in $0.5 \mathrm{M}-\mathrm{NaOH}$ and treated for $6 \mathrm{~h}$ at $25^{\circ} \mathrm{C}$ or $18 \mathrm{~h}$ at $4{ }^{\circ} \mathrm{C}$. The amount of released peptides was determined by either basic hydrolysis with ninhydrin quantitation or acidic hydrolysis followed by automatic amino-acid analysis. The data in Table I show good agreement between the two methods of analysis and also show that the longer period of base treatment in the cold released an amount of peptide equivalent to that released at the higher temperature. The cold treatment was used in order to avoid possible degradation of the peptide by the base at the higher temperatures.

Table 2 shows the amino acids produced by acid hydrolysis of the peptide material released from the wall by treatment at $4{ }^{\circ} \mathrm{C}$ for $\mathrm{I} 8 \mathrm{~h}$ in $0.5 \mathrm{M}-\mathrm{NaOH}$.

Treatment of the wall with $25 \% \mathrm{NH}_{4} \mathrm{OH}$ at $37^{\circ} \mathrm{C}$ for $3 \mathrm{~h}$ also released much of the peptide, although there was considerable variation in the amount released - typically, between 60 and $75 \%$. Gel filtration showed that this material consisted of a disperse, high molecular weight peak, with an average weight of approximately I00000 daltons. Gel filtration in the presence of urea established that this material was not an aggregate held together by non-covalent linkages. On a column of Bio Gel A $0.5 \mathrm{M}$ in $6 \mathrm{M}$-urea, the $\mathrm{NH}_{4} \mathrm{OH}$-released material gave a peak similar to that obtained by gel filtration without urea. A portion of the $\mathrm{NH}_{4} \mathrm{OH}$ extract, treated with $0.5 \mathrm{~N}-\mathrm{NaOH}$ overnight at $4{ }^{\circ} \mathrm{C}$ and then made to $6 \mathrm{M}$ with 
Table 2. Amino-acid composition of material removed from the hyphal wall by treatment with $0.5 \mathrm{~N}-\mathrm{NaOH}$

$\begin{array}{lclc}\begin{array}{c}\text { Amino } \\ \text { acid }\end{array} & \begin{array}{c}\text { Percentage of total } \\ \text { micromoles }\end{array} & \begin{array}{c}\text { Amino } \\ \text { acid }\end{array} & \begin{array}{c}\text { Percentage of total } \\ \text { micromoles }\end{array} \\ \text { Asp } & 12.43 & \text { Met } & \text { I.2I } \\ \text { Thr } & 8.18 & \text { Ile } & 3.26 \\ \text { Ser } & 8.64 & \text { Leu } & 6.85 \\ \text { Glu } & 10.24 & \text { Tyr } & 2.91 \\ \text { Pro } & 0.72 & \text { Phe } & 2.25 \\ \text { Gly } & 13.36 & \text { Lys } & 6.43 \\ \text { Ala } & 10.85 & \text { His } & 2.26 \\ \frac{1}{2} \text { Cys } & 0.71 & \text { Arg } & 3.67 \\ \text { Val } & 5.82 & & \end{array}$

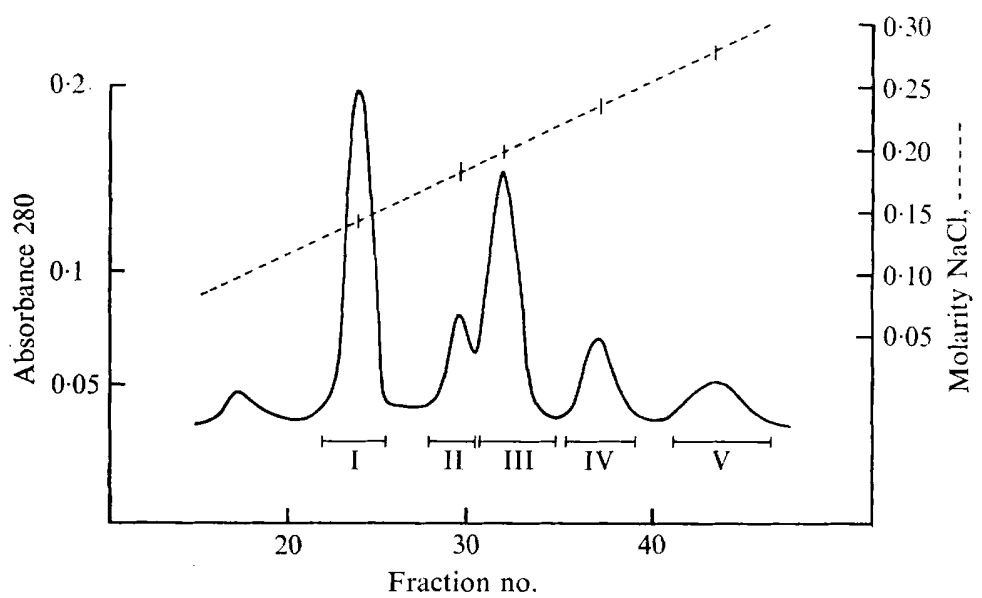

Fig. 2. DEAE-cellulose chromatography of hyphal wall peptides. Column dimensions were $2 \times 20 \mathrm{~cm}$ and the buffer used $0.00 \mathrm{I}$ M-tris- $\mathrm{HCl}, \mathrm{pH} \mathrm{7.4}$. A linear gradient of $\mathrm{NaCl}$ was used for elution. Ten-ml fractions were collected. Numbered bars represent the fractions which were pooled to form the peptide fractions I to $\mathrm{V}$.

urea, gave a single low molecular weight peak with the same elution volume as the peptides released from the hyphal wall by direct $\mathrm{NaOH}$ treatment.

Strong acid $(\mathrm{I} \cdot \mathrm{O} \mathrm{N}-\mathrm{HCl})$ was also effective in removing peptide from the wall. This material was found to be similar to that removed from the wall by $\mathrm{NaOH}$, as co-chromatography on sieving the gel showed no difference in the elution pattern of the peptides separated from the wall by these two methods.

Separation and amino-acid composition of the released peptides. The hyphal wall peptides were prepared by $0.5 \mathrm{M}-\mathrm{NaOH}$ treatment of the wall, desalted and applied to a column of DEAE cellulose. The column was developed as described. A typical elution pattern is given in Fig. 2, showing the five major components that were separated. They are referred to as fractions I to $\mathrm{V}$.

The elution pattern shown in Fig. 2 has been confirmed, both for elution position and the relative proportion of the fractions, by many repetitions with samples taken from different wall preparations and from different growths of mycelia. Further, fractions which were separated by DEAE cellulose chromatography and then rerun in the presence of urea exhibited no difference in elution profiles. This showed that the peptides obtained by base 


\section{Table 3. Amino acid composition of DEAE fractions $I$ to $V$}

Values for each amino acid shown as percentage of total micromoles of amino acids present in each sample.

\begin{tabular}{|c|c|c|c|c|c|}
\hline Amino acid & I & II & III & IV & $\mathrm{V}$ \\
\hline Asp & $15 \cdot 13$ & 14.64 & 14.04 & 15.00 & $17 \cdot 30$ \\
\hline Thr & $8 \cdot 19$ & $7 \cdot 44$ & $7 \cdot 13$ & $7 \cdot 50$ & 6.62 \\
\hline Ser & $8 \cdot 73$ & $8 \cdot 14$ & $7 \cdot 52$ & $6 \cdot 78$ & $6 \cdot 22$ \\
\hline Glu & 10.51 & 10.84 & I I $\cdot 22$ & $1 I \cdot I 5$ & 13.02 \\
\hline Gly & I I $\cdot 23$ & $13 \cdot 70$ & $14 \cdot 72$ & $12 \cdot 38$ & I I 80 \\
\hline Ala & 13.54 & I $2 \cdot 80$ & $11 \cdot 30$ & $11 \cdot 96$ & $11 \cdot 17$ \\
\hline Cys & 0.70 & - & 0.78 & - & - \\
\hline Val & $8 \cdot 70$ & $7 \cdot 56$ & 7.02 & $7 \cdot 15$ & $6 \cdot 05$ \\
\hline Met & 0.42 & 0.90 & 0.85 & 0.39 & 0.30 \\
\hline Ile & 4.00 & $3 \cdot 66$ & 3.60 & 4.00 & $4 \cdot 58$ \\
\hline Leu & $6 \cdot 18$ & $6 \cdot 56$ & 6.66 & $6 \cdot 57$ & $6 \cdot 56$ \\
\hline Tyr & $\mathrm{I} \cdot 70$ & $3 \cdot 19$ & $3 \cdot 62$ & 4.00 & $2 \cdot 97$ \\
\hline Phe & 3.92 & 4.57 & 5.04 & $5 \cdot 54$ & $6 \cdot 5 \mathrm{I}$ \\
\hline His & $1 \cdot 52$ & $\mathrm{I} \cdot 4 \mathrm{I}$ & $1 \cdot 57$ & $1 \cdot 71$ & 0.70 \\
\hline Lys & $4 \cdot 02$ & $2 \cdot 73$ & 2.58 & $2 \cdot 73$ & 0.77 \\
\hline Arg & 0.72 & $1 \cdot 17$ & $I \cdot 51$ & $2 \cdot 19$ & $4 \cdot 80$ \\
\hline Pro & 0.70 & 0.60 & $0 \cdot 72$ & 0.86 & 0.54 \\
\hline $\begin{array}{l}\text { Calculated mole- } \\
\text { cular weight } *\end{array}$ & I 4 I 25 & 17366 & 20797 & I 8840 & 7016 \\
\hline $\begin{array}{l}\text { Basic residue } \\
\text { to acid residue } \\
\text { ratio } \nmid\end{array}$ & 0.244 & $0 \cdot 208$ & 0.224 & 0.253 & 0.206 \\
\hline Unknown I & 949 & 763 & 503 & None & $238 \mathrm{I}$ \\
\hline Unknown II $\ddagger$ & 79 & 52 & 47 & 405 & I 507 \\
\hline
\end{tabular}

treatment of the hyphal wall and separated by DEAE chromatography are normal constituents of the wall, do not change in composition owing to age differences of the mycelia or methods of extraction, and are not artefacts of aggregation caused by interaction of the peptides.

Material obtained by $\mathrm{NaOH}$ treatment of the high molecular weight fraction removed from the wall by $25 \% \mathrm{NH}_{4} \mathrm{OH}$ or of peptides removed from the wall with acid, was also chromatographed on DEAE cellulose. The elution pattern was the same as that of peptides obtained by direct treatment of the wall with $\mathrm{NaOH}$. Co-chromatography of the separated fractions from all types of preparations revealed identical elution behaviour.

Fractions I to $\mathrm{V}$ were concentrated, desalted and subjected to acid hydrolysis. The amino acids present were determined by automatic analysis. The results of three separate preparations, given as the average values for each amino acid, are shown in Table 3. Determination of tryptophan was not performed. The ratios of micromoles of basic (lysine, histidine and arginine) to acidic (glutamic and aspartic acids) residues are also given for each fraction. Although the total acidic residues varied between the separated fractions, the ratio remained fairly constant.

Amino-acid analysis also showed the presence of two unidentified compounds, one (unknown I) having an acidic and the other (unknown II) a basic character. These components were present in considerable quantities, but no further attempts have been made 


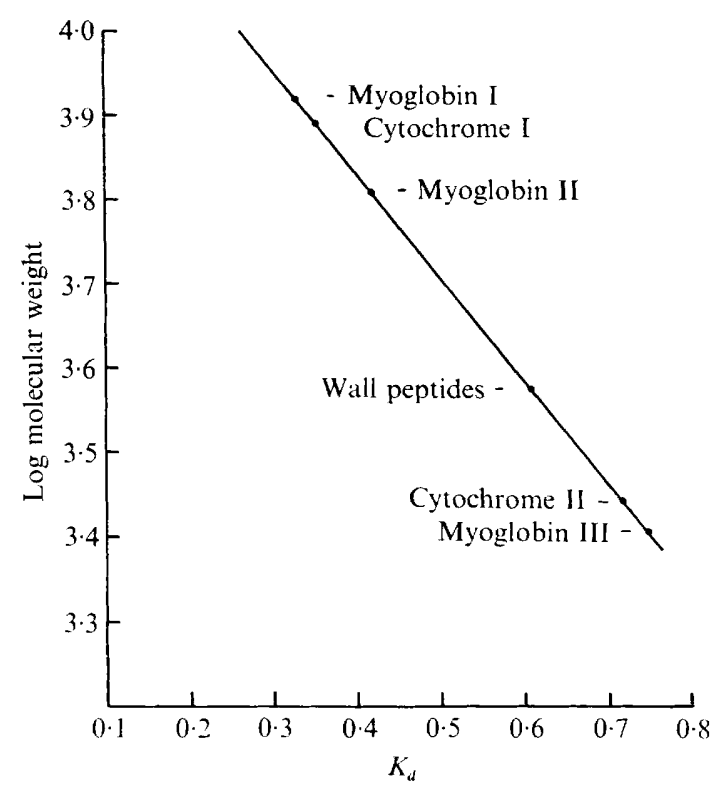

Fig. 3. Estimation of molecular weights of the hyphal wall peptides by gel filtration in the presence of urea. Calibration standards are cyanogen bromide fragments of myoglobin (myoglobin I, II and III) and cytochrome $c$ (cytochrome I and II). The location of the elution position of the hyphal wall peptides is indicated.

to identify them. However, as the unknown I was absent in fraction IV, and the quantities present in the other fractions were significant, these unknown components warrant further study.

Molecular weight of the peptides. Molecular weights of the separated fractions were determined by gel filtration in the presence of urea and high salt. Under low salt conditions, these peptides bind to the gel, with an increase in the volume needed to elute the fractions from the column. The results of the high-salt chromatography are shown in Fig. 3, with the distribution coefficient $\left(K_{d}\right)$ of the standards and the unknown plotted against the log of the molecular weights. The $K_{d}$ was calculated by the following formula:

$$
K_{a}=\frac{V_{t}-V_{e}}{V_{t}-V_{o}}
$$

where $V_{t}$ is the elution volume of tritiated water, $V_{o}$ the elution volume of bovine serum albumin and haemoglobin (which elute at the void volume of the column), and $V_{e}$ the elution volume of the molecule in question. Each point on the calibration line represents the average of three separate determinations. There was no difference in the elution volumes of either standard or peptide fractions when they were run separately or together. The estimated molecular weight for all peptide fractions was 3800 daltons. A mixture of peptides produced a single, symmetrical peak with a $K_{d}$ of 0.607 . Thus by this technique there was no detectable difference between the molecular weights of any of the fractions which could be separated by DEAE cellulose chromatography.

A comparison of the molecular weight estimated by gel filtration and the molecular weight estimated from amino acid analysis shows a considerable discrepancy. As shown in Table 3, the estimated molecular weights of the fractions ranged from about 7000 to 20000 daltons. Dialysis membranes which retain cytochrome $c$ in tris- $\mathrm{HCl}$ buffer at $\mathrm{pH} 7 \cdot 4$ would not 

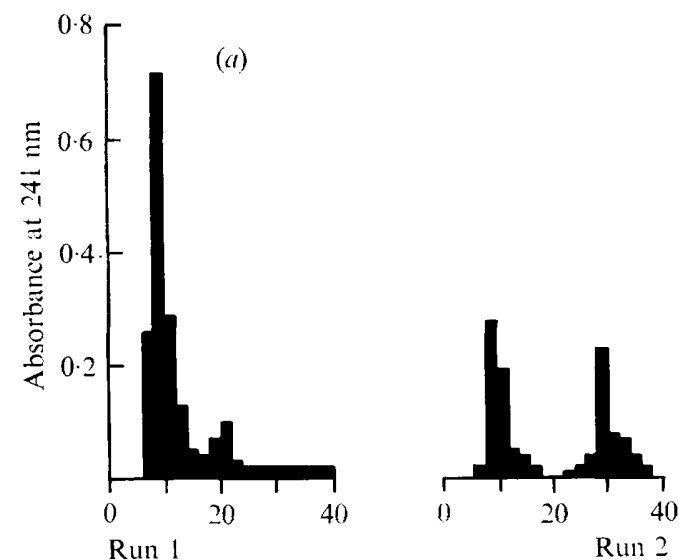

Fraction no.

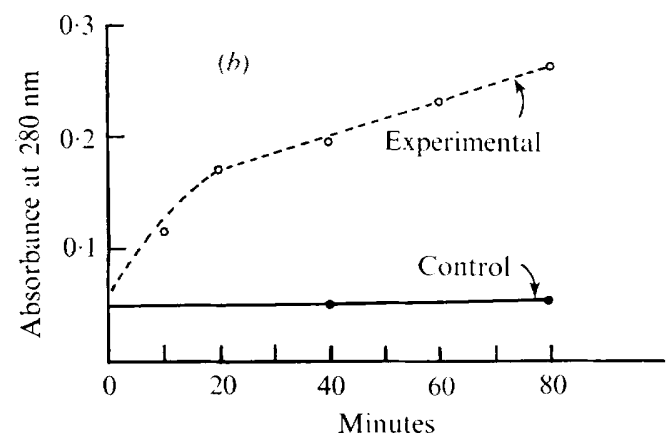

Fig. 4. Release of peptides from material extracted from the cell wall by $\mathrm{NH}_{4} \mathrm{OH}$. (a) (Run I) Gel filtration on $\mathrm{P}-\mathrm{I} 50$ column of untreated $\mathrm{NH}_{4} \mathrm{OH}$ extract. Fractions five to fifteen were pooled; (Run 2) gel filtration on same column of pooled material from (I) after 80 min in $0.5 \mathrm{M}-\mathrm{NaOH}$ at room temperature. (b) Increase in absorbance at $24 \mathrm{I} \mathrm{nm}$ of pooled material during treatment with $0.5 \mathrm{~N}-\mathrm{NaOH}$.

retain the hyphal wall peptides, either as a mixture or as separate fractions. It would thus appear that the lower value obtained by gel filtration is the correct one and that the values obtained from the amino-acid analysis are the result of some degree of heterogeneity within the separated fractions. Attempts to resolve the peptide fractions further were not successful.

Linkage of the peptides. The lability of the linkages of the wall peptide to alkali is indicative of the presence of covalent bonds between a sugar and either serine or threonine $(O$-glycosyl serine or $O$-glycosyl threonine) (Neuberger, Gottschalk \& Marshall, I966). To exclude the possibility of an ester bond, which is also base-labile, hyphal wall was suspended in tetrahydrofuran with $0.3 \mathrm{M}^{-\mathrm{LiBH}_{4}}$ and boiled under reflux for $\mathrm{Io}$ h. If the bonds holding the peptides and carbohydrates together were of the ester type, this procedure should have released them (Gottschalk \& Murphy, 196I). However, $92 \%$ (average of three experiments) of the peptide remained with the sedimentable residue after this treatment. This provides evidence for the release of the peptides by a typical $\beta$-elimination reaction.

$\mathrm{NaOH}$ treatment of the high molecular weight peptide material removed from the hyphal 
Table 4. Radioactivity of alanine and serine recovered by thin-layer chromatography after acid hydrolysis of hyphal wall peptide released by different methods

\begin{tabular}{|c|c|c|c|}
\hline $\begin{array}{c}\text { Method of } \\
\text { peptide release }\end{array}$ & $\begin{array}{l}\text { C.p.m. applied } \\
\text { to chromatogram }\end{array}$ & $\begin{array}{l}\text { C.p.m. } \\
\text { recovered }\end{array}$ & $\begin{array}{l}\text { Percentage of total } \\
\text { c.p.m. applied }\end{array}$ \\
\hline $\begin{array}{l}\text { Acid }(\mathrm{I} \cdot \mathrm{O} \mathrm{N}-\mathrm{HCl}) \\
\text { Alanine } \\
\text { Serine }\end{array}$ & 570 & $\begin{array}{r}- \\
51 \\
187\end{array}$ & $\begin{array}{r}\overline{-} \\
8 \cdot 9 \\
32 \cdot 8\end{array}$ \\
\hline Total & & 238 & $41 \cdot 7$ \\
\hline $\begin{array}{l}\text { Base }(0.5 \mathrm{~N}-\mathrm{NaOH}) \\
\text { Alanine } \\
\text { Serine }\end{array}$ & 802 & $\begin{array}{l}- \\
53 \\
65\end{array}$ & $\begin{array}{l}-\overline{6 \cdot 8} \\
8 \cdot 0\end{array}$ \\
\hline Total & & 118 & $14 \cdot 8$ \\
\hline $\begin{array}{l}\text { Base }\left(0 \cdot 25 \mathrm{~N}-\mathrm{NaOH}+0.3 \mathrm{M}-\mathrm{NaBH}_{4}\right) \\
\text { Alanine } \\
\text { Serine }\end{array}$ & 640 & $\begin{array}{r}- \\
120 \\
55\end{array}$ & $\begin{array}{r}- \\
18 \cdot 8 \\
8 \cdot 6\end{array}$ \\
\hline Total & & 175 & $27 \cdot 4$ \\
\hline
\end{tabular}

wall with $\mathrm{NH}_{4} \mathrm{OH}$ provided evidence for the existence of $O$-glycosyl serine within this complex. A solution of the material extracted by $\mathrm{NH}_{4} \mathrm{OH}$ was placed on a column of Bio-Gel P-I 50 and the high molecular weight peak pooled and concentrated. This was made to $0.5 \mathrm{M}-\mathrm{NaOH}$ and a portion taken for absorbance measurements. After $80 \mathrm{~min}$, the remainder was again run on the P-I50 column. The results are depicted in Fig. 4. The increase in absorbance at $24 \mathrm{I} \mathrm{nm}$ was caused by the production of dehydroserine (Carubelli, Bhavanandan \& Gottschalk, 1965), which is a product of the base-catalysed $\beta$-elimination reaction that breaks the $O$-glycosyl serine bond. This was accompanied by the appearance of a low molecular weight fraction from the gel-filtration column. If this reaction was continued, the low molecular peak was enriched at the expense of the high molecular weight fraction until the latter disappeared. From these results, we concluded that the material extracted from the wall by $\mathrm{NH}_{4} \mathrm{OH}$ is actually small peptides joined to a branched carbohydrate linker by $O$-glycosyl serine bonds, which forms a much larger molecule in vivo.

Acid treatment of the walls released low molecular weight peptide material which was similar in behaviour to that released by treatment with $\mathrm{NaOH}$. If acid-extracted material was dissolved in $0.5 \mathrm{~N}-\mathrm{NaOH}$ and absorbance of the solution at $24 \mathrm{Imm}$ recorded, there was no change over a period of $3 \mathrm{~h}$. This showed that the released material, although similar to that removed from the wall by strong base treatment, was no longer capable of undergoing a $\beta$-elimination reaction. Therefore, the release of the peptides by acid probably resulted from an attack on the sugar moiety of the $O$-glycosyl amino-acid linkage. This is in accord with the findings of Sentandreu \& Northcote (1968) concerning the acid-sensitivity of these linkages in yeast cell-wall glycopeptide.

If $O$-glycosyl serine bonds are present between the peptide and carbohydrate, treatment with base followed by acid hydrolysis should demonstrate a loss of the serine molecules in this linkage. These linkage molecules can be recovered by reduction of the peptide with $\mathrm{NaBH}_{4}$ before acid hydrolysis (Tanaka, Bertolini \& Pigman, 1964). This will produce alanine by hydrogenation of dehydroserine, which is formed by the $\beta$-elimination reaction which cleaves the $O$-glycosyl serine bond. If radioactive serine is incorporated into the cell wall peptides and the walls treated with $\mathrm{NaBH}_{4}$ in base, an increase in the radioactivity of alanine and a decrease in that of serine should be observed. The results of such an experiment are shown in Table 4 . The peptide of a serine-requiring strain was labelled with 
$\left[{ }^{14} \mathrm{C}\right]$ serine. Peptides were removed from the wall with either $\mathrm{NaOH}, \mathrm{NaOH}+\mathrm{NaBH}_{4}$, or $\mathrm{HCl}$. They were then hydrolysed with $\mathrm{HCl}$ and the resulting amino acids separated by thinlayer chromatography. The radioactivity of the alanine and serine was then determined. Extraction by acid was used as the control as it was assumed that destruction of both serine and alanine was minimal with this treatment. Treatment with base alone showed a $75 \%$ reduction in labelled serine, with a small loss of alanine. Upon reduction with $\mathrm{NaBH}_{4}$ the same loss of serine was observed, but with a $147 \%$ increase in alanine. This conversion of serine to alanine by base treatment and reduction gave further evidence for the existence of $O$-glycosyl serine linkages between the peptides and a carbohydrate linker.

Digestion of the wall with chitinase and glusulase gave evidence as to the location of the peptide in the hyphal wall. After digestion with chitinase the residue was found to be free of glucosamine. However, at least $85 \%$ of the peptide components remained associated with the residue as compared to the buffer-treated controls. Measurement of peptide material remaining with the hyphal wall residue after digestion with glusulase is difficult, as this enzyme preparation is known to contain a protease (Holden \& Tracey, 1950). However, a considerable amount of low molecular weight peptide material was released by treatment of the digested residue with $\mathrm{NaOH}$. These results showed that although peptide material comprised a portion of the hyphal wall of this organism, there was no demonstrable covalent attachment of this component to other major constituents of the wall.

\section{DISCUSSION}

The results of this investigation partially confirm and extend the observations of previous workers concerning the occurrence of protein in the hyphal wall of Neurospora crassa. Our data on the amino-acid composition of the peptides released from the wall are similar to the data on the amino acids of hydrolysed whole wall reported by Livingston (1969). However, they are substantially different from those of Mahadevan \& Tatum (1965) and Manocha \& Colvin (1967). In the former, separation and identification was by paper chromatography and only seven amino acids were found. We have found all normally occurring protein amino acids to be present, with the exception of hydroxyproline, whose absence has been noted before (Manocha \& Colvin, 1967). Manocha \& Colvin (1967) found an absence of valine and only trace amounts of arginine. We have found these amino acids to be present in significant amounts -5.8 and $3.6 \%$ of total moles respectively. They also reported higher (approx. $5 \%$ ) values for both glutamic and aspartic acids than shown by the present work. The data reported here also give a minimum value for the protein content of the hyphal wall of $N$. crassa $-8.63 \%$ by weight. This is less than reported previously (de Terra \& Tatum, I963; Manocha \& Colvin, I967) on the basis of whole wall hydrolysis. However, there are some free amino acids remaining on the wall residue after base treatment (C. R. Wrathall, unpublished results) which could give rise to an overestimate of protein by such hydrolysis, as well as differences in the amino acids recovered from such treatment.

The finding of significant amounts of peptide material in the residue after enzymatic digestion of the chitin or $\beta$-I,3-carbohydrate polymer of the walls, also confirms earlier work (Manocha \& Colvin, 1967; Hunsley \& Burnett, 1970). The hypothesis of Hunsley \& Burnett (1970), that the peptide component of the wall is part of a glycoprotein reticulum with no demonstrable covalent attachment to the rest of the wall, is supported by our results. Our experiments, in which the high molecular weight complex was extracted from the hyphal walls by $\mathrm{NH}_{4} \mathrm{OH}$ and small peptides released from this complex by subsequent $\mathrm{NaOH}$ catalysed $\beta$-elimination reactions, support their hypothesis. The initial extraction with 
ammonia may have been strong enough to cleave a few bonds, solubilizing the complex, while the second treatment with stronger base was needed to effect the complete destruction of the carbohydrate-peptide linkages.

Acid extraction of the hyphal wall also released peptide material which was similar in its molecular weight and DEAE cellulose elution profile to that removed by $\mathrm{NaOH}$ but which did not give, on treatment with $\mathrm{NaOH}$, the increase in absorbance at $24 \mathrm{I} \mathrm{nm}$ which is characteristic of $\beta$-elimination involving $O$-glycosyl serine. The acid treatment probably destroyed the sugar which was involved in the bond between the carbohydrate and the peptide and released the latter (Sentandreu \& Northcote, I968). The peptides that were removed from the hyphal wall by $\mathrm{NaOH}$ or $\mathrm{HCl}$ therefore appear to have been released from the reticulum itself, rather than freed by the breaking of bonds which attach them to the rest of the wall.

The structure of the glycopeptide reticulum of the wall, in light of the above, is of considerable interest. First, the carbohydrate linker must be a highly branched polymer with a number of reducing ends, as the $O$-glycosyl serine linkage involves the anomeric carbon of the carbohydrate. Since the usual carbohydrate branching utilizes rather than generates anomeric carbons, the branching of this linker must be of an unusual nature. A molecule such as this, with phosphate links between the carbohydrate chains, has been suggested to occur in the galactomannan-peptide of the yeast Cladosporium wernecki (Lloyd, 1970). Secondly, the fact that the separation by DEAE cellulose chromatography of the peptides extracted from the hyphal wall by both acid and base treatment is highly repeatable indicates that the structure of the reticulum is closely controlled. The possibility that heterogeneity arises through a random destruction of the terminal residues of the peptides caused by extraction methods is eliminated by this repeatable separation, unless destruction occurs at specific locations in each molecule. The molecular weights of the separated peptides, as determined by molecular-sieve chromatography, are very similar. This finding also indicates a stringent control of the structure of the glycopeptide reticulum. The heterogeneity of the separated peptides, as shown by the molecular weights calculated from the amino-acid composition, indicates that some differences in the structure of the peptides are permissible but that these must be relatively minor.

Amino acid analysis of the separated peptides showed the acidic and hydrophilic nature of these molecules. However, the differences in quantity of some of the amino acids, in particular arginine, lysine, glutamic and aspartic acids and the unknowns I and II, show that there are distinct differences between the peptide fractions. The similarity of the basic to the acidic residue ratio for each of the fractions supports the idea that there is a general similarity in the charge distribution within the reticulum.

This investigation provides the first evidence for the subunit structure of the glycopeptide reticulum of the hyphal wall of Neurospora crassa and also provides data which may be of some value in speculations on the function of the peptide component of the hyphal walls. Manocha \& Colvin (1967) have argued for a strictly structural function for the peptide fraction. However, other hypothesis concerning the function of the wall peptides have been proposed. Slayman \& Slayman (1970) proposed that the acidic residues of the peptides of the wall may be an 'in-transit' holding point for $\mathrm{Na}^{+}$and $\mathrm{K}^{+}$ions before they reach the cell membrane for transport, providing an exogenous pool of these ions which is closely associated with each cell. The results here show substantial quantities of charged amino acid residues in each peptide fraction but with very similar acidic-basic residue ratios. This would support the hypothesis that the peptides acted as an ion-exchange storehouse for cations as well as anions. The quantity of ions present on the hyphal wall would depend 
upon the $\mathrm{pH}$ of the medium in which the cells were grown but still would give the cell an immediately available source of many different ions, rather than depend upon simple diffusion of these ions through the hyphal wall.

Yabuki \& Fukui (1970) have described a fraction, isolated from the hyphal walls of Aspergillus oryzae, which prevents the binding of $\alpha$-amylase to the hyphal walls. This factor was extracted by base and behaved in a manner similar in some respects to the peptides described here. Their findings imply that there is a unique binding site on the hyphal wall for the enzyme $\alpha$-amylase and that this site can be blocked by a 'masking factor'. The peptides we have obtained from the wall of Neurospora crassa would be excellent candidates for the binding sites for various enzymes which are known to be extracellular in this organism. The enzyme invertase, which is excreted into the medium by Neurospora, is known to contain hexosamine (Metzenberg, I963). If the amino groups of this carbohydrate prosthetic group are not acetylated, the carboxyl groups of the glutamic and aspartic acids of the wall peptide would provide excellent binding sites for this enzyme. The $\alpha$-amylase of $A$. oryzae is also a glycoprotein (Yabuki \& Fukui, 1970) and could be bound to the wall in a similar manner. Eylar (1965) has postulated that the carbohydrate portion of glycoproteins is necessary for their excretion into the extracellular space. In the case of the fungi, one could postulate that the wall peptides would bind these enzymes until a specific substrate occurs in the medium. A particular enzyme, or group of enzymes, needed to process this substrate would then be released from the wall by a now unknown mechanism and the enzymes replaced on the wall by excretion from the cell. Preliminary experiments from this laboratory show that peptides isolated from the walls of cells grown on maltose have less of peptide fraction II than those grown on sucrose. The use of these peptides as binding sites for extracellular enzymes would help to explain the presence of protein-lined pores in the cell wall (Manocha \& Colvin, 1967). The molecular sieving properties of the cell wall (Trevithick \& Metzenberg, 1966a,b) might also be partially attributed to these binding sites on the protein lining these pores. The diversity which we have shown in the peptide fraction of the hyphal wall lends support to the argument that a physiological, as opposed to structural, role may be assigned to this wall component. The actual role that they may play in the function of the fungal cell remains to be elucidated.

The results of this investigation sustain the use of the term 'remarkable' to describe the glycoprotein component of the hyphal wall of Neurospora crassa by Hunsley \& Burnett (1970). The results of the acid and base solubilization presented here show that this wall component is made up of numerous subunits but that the structure of the larger polymer is remarkably constant in terms of the peptides present. The fact that these peptides differ in their amino acid composition gives evidence for the necessity of retaining a specific structure and indicates that this portion of the hyphal wall is a very important one in the maintenance of normal growth in this organism.

This investigation was supported by a grant from the National Institutes of Health (GMI6224) and a National Institutes of Health post-doctoral fellowship (5-FO-2 GM-4564I) to C.R.W. The helpful discussions and advice of Dr J. R. Wrathall are greatly appreciated. 


\section{REFERENCES}

BARTNICKI-GARCIA, S. (I968). Cell wall chemistry, morphogenesis and taxonomy of fungi. Annual Review of Microbiology 22, 87-108.

Carubelli, R., Bhavanandan, V. P. \& Gottschalk, A. (1965). Studies on glycoproteins. XI. The $O$-glycosidic linkage of $\mathrm{N}$-acetyl-galactosamine to seryl and threonyl residues in ovine submaxillary gland glycoprotein. Biochemica et biophysica acta ror, 67-82.

Chang, P. L. Y. \& Trevithick, J. R. (1972a). Release of wall-bound invertase and trehalase in Neurospora crassa by hydrolytic enzymes. Journal of General Microbiology 7o, 13-22.

Chang, P. L. Y. \& TRevithick, J. R. (1972b). Distribution of wall-bound invertase during the asexual lifecycle of Neurospora crassa. Journal of General Microbiology 7o, 23-29.

EBerHART, B. M. (196I). Exogenous enzymes of Neurospora conidia and mycelia. Journal of Cellular and Comparative Physiology 58, I $1-16$.

Eddy, A. A. (1958). The structure of the yeast cell wall. II. Degradative studies with enzymes. Proceedings of the Royal Society B r49, 425-440.

EYLAR, E. H. (1965). On the biological role of glycopeptides. Journal of Theoretical Biology Io, 89-I I 3.

Gornall, A. G., Bardawill, C. S. \& David, M. M. (I949). Determination of serum protein by means of the biuret reaction. Journal of Biological Chemistry 177, 75I-766.

Gottschalk, A. \& Murphy, W. H. (196I). Studies on mucoproteins. IV. The linkage of the prosthetic group to the protein core in ovine submaxillary gland mucoprotein. Biochemica et biophysica acta $46,8 \mathrm{I}-90$.

Gross, E. ( 1967). The cyanogen bromide reaction. In Methods in Enzymology. Enzyme Structure, vol. II. Edited by C. H. W. Hirs. New York: Academic Press.

Holden, M. \& Tracey, M. V. (I950). A study of enzymes that can break down tobacco-leaf components. 2. Digestive juice of Helix on defined substrates. Biochemical Journal 47, 407-444.

Hunsley, D. \& BurnetT, J. H. (1970). The ultrastructural architecture of the walls of some hyphal fungi. Journal of General Microbiology 62, 203-2 18.

Korn, E. D. \& Northcote, D. H. (1960). Physical and chemical properties of polysaccharides and glycoproteins of the yeast cell wall. Biochemical Journal 75, $12-17$.

LiVINGSTON, L. R. (I969). Locus-specific changes in cell wall composition characteristic of osmotic mutants in Neurospora crassa. Journal of Bacteriology 99, 85-90.

LLOYD, K. O. (1970). On the structure of a peptido-phosphogalactomannan complex from a black yeast, Cladosporium wernecki. FEBS Letters II, 9I-94.

Lowry, O. H., Rosebrough, N. J., Farr, A. L. \& Randall, R. J. (I951). Protein measurement with the Folin phenol reagent. Journal of Biological Chemistry 193, 265-275.

Mahadevan, P. R. \& TAtum, E. L. (1965). Relationship of the major constituents of the Neurospora crassa cell-wall to wild-type and colonial morphology. Journal of Bacteriology 90, I073-I08I.

Mahadevan, P. R. \& MahadkaR, U. R. (1970). Role of enzymes in growth and morphology of Neurospora crassa: Cell-wall-bound enzymes and their possible role in branching. Journal of Bacteriology ror, 94I-947.

Manocha, N. S. \& Colvin, J. R. (1967). Structure and composition of the cell wall of Neurospora crassa. Journal of Bacteriology 94, 202-2 12.

METZENBERG, R. L. (1963). The localization of $\beta$-fructofuranosidase in Neurospora. Biochemica et biophysica acta $77,455-465$.

Neuberger, A., Gottschalk, A. \& Marshall, R. D. (1966). Carbohydrate-peptide linkages in glycoproteins and methods for their detection. In Glycoproteins. Edited by A. Gottschalk. Amsterdam, Holland: Elsevier Publishing Co.

Nurminen, T., Oura, E. \& Suomalainen, H. (1970). The enzymic composition of the isolated cell wall and plasma membrane of baker's yeast. Biochemical Journal II6, 6I-69.

Rosen, H., BeraRd, C. W. \& Levenson, S. M. (I962). A simplified procedure for automatic amino acid analysis. Analytical Biochemistry 4, 2 I 3-22 I.

Sentandreu, R. \& Northcote, D. H. (1968). The structure of a glycopeptide isolated from the yeast cell wall. Biochemical Journal ro9, 419-432.

Slayman, C. W. \& Slayman, C. L. (1970). Potassium transport in Neurospora. Evidence for a multisite carrier at high pH. Journal of General Physiology 55, 758-786.

Spackman, D. H., Stein, W. H. \& MoORE, S. (1958). Automatic recording apparatus for use in the chromatography of amino acids. Analytical Chemistry 30, I 190-1 206. 
TANAKA, K., Bertolini, M. \& Pigman, W. (1964). Serine and threonine glycosidic linkages in bovine submaxillary mucin. Biochemical and Biophysical Research Communications 16, 404-409.

De Terra, N. \& TAtum, E. L. (1963). A relationship between cell wall structure and colonial growth in Neurospora crassa. American Journal of Botany 5o, 669-677.

Trevithick, J. R. \& Metzenberg, R. L. (I966a) Molecular sieving by Neurospora cell walls during secretion of invertase isozymes. Journal of Bacteriology 92, 1010-10I5.

Trevithick, J. R. \& Metzenderg, R. L. (1966 b). Genetic alteration of pore size and other properties of the Neurospora cell wall. Journal of Bacteriology 92, 1016-1020.

VoGeL, H. J. (1964). Distribution of lysine pathways among fungi: evolutionary implications. American Naturalist 98, 435-446.

YABUKI, M. \& FUKUI, S. (I970). Presence of binding site for $\alpha$-amylase and of masking protein for this site on mycelial cell wall of Aspergillus oryzae. Journal of Bacteriology 104, $138-144$. 